\title{
Ozone-induced lung function decrements do not correlate with early airway inflammatory or antioxidant responses
}

\author{
A. Blomberg*, I.S. Mudway ${ }^{+}$, C. Nordenhäll*, H. Hedenström", F.J. Kelly ${ }^{+}$, \\ A.J. Frew*, S.T. Holgate*, T. Sandström*
}

Ozone-induced lung function decrements do not correlate with early airway inflammatory or antioxidant responses. A. Blomberg, I.S. Mudway, C. Nordenhäll, H. Hedenström, F.J. Kelly, A.J. Frew, S.T. Holgate, T. Sandström. (C)ERS Journals Ltd 1999.

ABSTRACT: This study sought to clarify the early events occurring within the airways of healthy human subjects performing moderate intermittent exercise following ozone challenge.

Thirteen healthy nonsmoking subjects were exposed in a single blinded, crossover control fashion to 0.2 parts per million (ppm) $\mathrm{O}_{3}$ and filtered air for $2 \mathrm{~h}$, using a standard intermittent exercise and rest protocol. Lung function was assessed pre- and immediately post-exposure. Bronchoscopy was performed with endobronchial mucosal biopsies, bronchial wash (BW) and bronchoalveolar lavage (BAL) $1.5 \mathrm{~h}$ after the end of the exposure period. Respiratory tract lining fluid (RTLF) redox status was assessed by measuring a range of antioxidants and oxidative damage markers in BW and BAL fluid samples.

There was a significant upregulation after $\mathrm{O}_{3}$ exposure in the expression of vascular endothelial P-selectin $(p<0.005)$ and intercellular adhesion molecule-1 $(p<0.005)$. This was associated with a 2 -fold increase in submucosal mast cells $(p<0.005)$ in biopsy samples, without evidence of neutrophilic inflammation, and a decrease in BAL fluid macrophage numbers $(1.6$-fold, $p<\mathbf{0 . 0 0 5})$, with an activation of the remaining macrophage subset $(2.5$-fold increase in \% human leukocyte antigen (HLA)-DR+ cells, $\mathrm{p}<\mathbf{0 . 0 0 5}$ ). In addition, exposure led to a 4.5 -fold and 3.1-fold increase of reduced glutathione (GSH) concentrations, in $\mathrm{BW}$ and $\mathrm{BAL}$ fluid respectively $(\mathrm{p}<0.05)$, with alterations in urate and $\alpha$-tocopherol plasma/RTLF partitioning ratios $(p<0.05)$. Spirometry showed reductions in forced vital capacity $(p<0.05)$ and forced expiratory volume in one second $(p<0.01)$, with evidence of small airway narrowing using forced expiratory flow values $(\mathbf{p}<\mathbf{0 . 0 0 5})$.

Evidence was found of $\mathrm{O}_{3}$-induced early adhesion molecule upregulation, increased submucosal mast cell numbers and alterations to the respiratory tract lining fluid redox status. No clear relationship was demonstrable between changes in these early markers and the lung function decrements observed. The results therefore indicate that the initial lung function decrements are not predictive of, or causally related to the $\mathrm{O}_{3}$-induced inflammatory events in normal human subjects.

Eur Respir J 1999; 13: 1418-1428.
*Dept of Respiratory Medicine and Allergy, University Hospital, Umeå and National Institute for Working Life, Umeå, Sweden. ${ }^{+}$Lung Biology, Cardiovascular Research, The Rayne Institute, St Thomas' Hospital, London, UK. "Air Pollution Group/Immunopharmacology Group, University Medicine, Southampton General Hospital, Southampton, UK. "Dept of Clinical Physiology, University Hospital, Uppsala, Sweden.

Correspondence: T. Sandström

Dept of Respiratory Medicine and Allergy University Hospital

S-901 85 Umeå

Sweden

Fax: 4690141369

Keywords: Adhesion molecules glutathione

mast cells

ozone

P-selectin

Received: August 261998

Accepted after revision March 111999

Supported by the Swedish Asthma and Allergy Association, the Swedish Work Environmental Fund, The Swedish Heart and Lung Foundation and the Medical Research Council (UK).
Ambient concentrations of ozone, an oxidant gas associated with summertime photochemical smog, frequently exceed recommended safety levels ( 0.08 parts per million (ppm), hourly average) throughout Europe. Ozone concentrations have even been reported to exceed $0.2 \mathrm{ppm}$ over parts of central Europe when weather conditions favour its build up. At these concentrations, $\mathrm{O}_{3}$ is known to elicit a spectrum of symptoms in human subjects, characterized by immediate impairment of lung function (decrements in forced expiratory volume in one second (FEV1) and forced vital capacity (FVC) and increased airway resistance), and an evolving airway inflammation [1].

Human chamber studies have demonstrated $\mathrm{O}_{3}$-induced inflammation (airway neutrophilia) to be progressive up to $6 \mathrm{~h}$, and persistent until 18-24 h after exposure [2,3]. Within this late response window $(6-24 \mathrm{~h})$ a range of pro-in- flammatory mediators (interleukin (IL)-6, IL-8, granulocyte-macrophage colony-stimulating factor (GM-CSF), prostaglandin $(\mathrm{PG}) \mathrm{E}_{2}$ ) have been shown to be elevated in airway lavage following $\mathrm{O}_{3}[2-5]$. Inflammation at the level of the bronchial mucosa also occurs with increased neutrophil numbers, and with upregulation of the vascular endothelium intercellular adhesion molecule (ICAM)-1 [6]. In contrast, studies addressing inflammatory responses in humans earlier than $6 \mathrm{~h}$ after exposure are scarce. Airway neutrophilia occurring 1-3 h after exposure has been reported following exposure to high $\mathrm{O}_{3}$ concentrations $(0.3-0.4 \mathrm{ppm})$ with heavy exercise $[5,7]$. In addition, increased P-selectin levels in the vascular endothelium have recently been reported as early as $1.5 \mathrm{~h}$ after exposure to $0.12 \mathrm{ppm} \mathrm{O}_{3}$ with moderate intermittent exercise in healthy human subjects [8]. 
In contrast to the pattern of response observed for $\mathrm{O}_{3-}$ induced airway inflammation, decrements in FVC and FEV1 appear greatest immediately after exposure, resolving by $6 \mathrm{~h}$ after exposure [1]. Indices of airway narrowing and airway resistance appear somewhat more persistent, but also follow a different temporal profile to the inflammatory response [9]. Previous studies have indicated an inverse relationship between the magnitude of the immediate FEV1 decrements and neutrophilic inflammation in airway lavage, sampled 6-18 h after exposure $[2,10]$. Recently, a significant association has also been reported between $\mathrm{O}_{3}$-induced changes in airway resistance with comparative changes in bronchoalveolar lavage (BAL) fluid neutrophil numbers and the total protein concentration $18 \mathrm{~h}$ after exposure [6]. Consequently, although increased airway resistance may have some value in predicting subsequent damage, it provides limited information about the causation of the original lung function decrement.

The current study sought to clarify early events occurring after $\mathrm{O}_{3}$ challenge in human subjects performing moderate intermittent exercise. Based on previous findings, the possible upregulation of adhesion molecules, and alterations in cell populations within the submucosa as early markers of inflammation using bronchial biopsies were focused on. The impact of $\mathrm{O}_{3}$ on the respiratory tract lining fluid (RTLF) redox status was also examined by determining antioxidant (urate, ascorbate, reduced glutathione (GSH) and $\alpha$-tocopherol) and oxidative damage marker (malondialdehyde (MDA) and glutathione disulphide (GSSG)) concentrations within this compartment using airway lavage. It was thought that, as the initial interaction between inhaled $\mathrm{O}_{3}$ and the lung would occur at this interface, alterations in the concentration of these moieties would represent one of the earliest markers of the action of $\mathrm{O}_{3}$ on the lung. In addition to describing these early events, it was also sought to determine whether they were either causally related to, or predictable from, the magnitude of lung function dysfunction observed immediately after exposure.

\section{Subjects and methods}

\section{Subjects}

Thirteen subjects were recruited into this study: five female and eight male, median age 23 (range 20-31) yrs (table 1). All subjects underwent a screening procedure during which a detailed medical history was taken, with skin prick tests, electrocardiogram, assessment of lung function, blood counts and biochemistry, prior to approval for participation in this study. All subjects were healthy, nonatopics with normal lung function. No subject had a history of asthma or any other pulmonary disease. Furthermore, all subjects were nonsmokers. Challenge dates were rearranged if subjects experienced any form of respiratory infection within a 6-week period prior to exposure. Subjects were instructed to refrain from any form of dietary antioxidant supplementation or anti-inflammatory medication throughout the duration of this study. Informed consent was obtained and the study approved by the local Ethics Committee of Umeå University.

\section{Study design}

Subjects were exposed twice, once to filtered air and once to $0.2 \mathrm{ppm} \mathrm{O}_{3}$, using a whole body "walk in" environmental chamber as previously described [11]. Each exposure was $2 \mathrm{~h}$ in duration, during which subjects alternated between 15-min periods of exercise and rest.

Table 1. - Subject demographics with differential lavage fluid recoveries obtained $1.5 \mathrm{~h}$ after 0.2 parts per million (ppm) $\mathrm{O}_{3}$ and air exposures

\begin{tabular}{|c|c|c|c|c|c|c|c|c|c|c|c|}
\hline \multirow[b]{3}{*}{$\begin{array}{l}\text { Subject } \\
\text { No. }\end{array}$} & \multirow[b]{3}{*}{$\begin{array}{l}\text { Age } \\
\text { yrs }\end{array}$} & \multirow[b]{3}{*}{$\begin{array}{l}\text { Sex } \\
\mathrm{M} / \mathrm{F}\end{array}$} & \multirow[b]{3}{*}{$\begin{array}{l}\text { Height } \\
\mathrm{cm}\end{array}$} & \multirow[b]{3}{*}{$\begin{array}{l}\text { FEV1 } \\
\% \text { pred }\end{array}$} & \multirow[b]{3}{*}{$\begin{array}{l}\text { FVC } \\
\% \text { pred }\end{array}$} & \multicolumn{6}{|c|}{ Lavage volume recoveries $\mathrm{mL}$} \\
\hline & & & & & & \multicolumn{2}{|c|}{ BWI } & \multicolumn{2}{|c|}{ BWII } & \multicolumn{2}{|c|}{ BAL } \\
\hline & & & & & & Air & $\mathrm{O}_{3}$ & Air & $\mathrm{O}_{3}$ & Air & $\mathrm{O}_{3}$ \\
\hline 1 & 20 & M & 180 & 109 & 109 & 6.0 & 9.0 & 9.0 & 9.0 & 130 & 125 \\
\hline 2 & 23 & $\mathrm{~F}$ & 162 & 101 & 101 & 7.5 & 7.0 & 12.5 & 12.5 & 50 & 160 \\
\hline 3 & 23 & M & 172 & 82 & 87 & 5.0 & 7.0 & 12.0 & 9.0 & 150 & 150 \\
\hline 4 & 24 & M & 177 & 90 & 93 & 7.0 & 8.0 & 12.0 & 17.5 & 125 & 100 \\
\hline 5 & 25 & M & 184 & 113 & 120 & 7.5 & 7.5 & 10.0 & 10.0 & 95 & 100 \\
\hline 6 & 21 & M & 182 & 98 & 109 & 8.0 & 8.0 & 13.0 & 13.0 & 150 & 150 \\
\hline 7 & 24 & $\mathrm{~F}$ & 169 & 100 & 102 & 7.0 & 7.0 & 8.0 & 12.5 & 90 & 150 \\
\hline 8 & 23 & $\mathrm{~F}$ & 167 & 88 & 97 & 7.5 & 7.5 & 15.0 & 16.0 & 100 & 155 \\
\hline 9 & 31 & M & 179 & 97 & 96 & 9.0 & 10.0 & 12.5 & 14.0 & 80 & 100 \\
\hline 10 & 21 & $\mathrm{~F}$ & 168 & 98 & 99 & 10.0 & 7.5 & 15.0 & 10.0 & 130 & 130 \\
\hline 11 & 23 & M & 185 & 80 & 95 & 12.5 & 8.0 & 10.0 & 9.0 & 90 & 130 \\
\hline 12 & 28 & M & 185 & 95 & 96 & 7.0 & - & 10.0 & - & 160 & - \\
\hline 13 & 23 & $\mathrm{~F}$ & 175 & 95 & 95 & 7.5 & 8.0 & 12.5 & 11.0 & 150 & 160 \\
\hline Median & 23 & & 177 & 97 & 97 & 7.5 & 7.8 & 12.0 & 11.8 & 125.0 & 140.0 \\
\hline 25 th & 23 & $5 \mathrm{~F} / 8 \mathrm{M}$ & 169 & 89 & 95 & 7.0 & 7.3 & 10.0 & 9.5 & 90.0 & 112.5 \\
\hline 75th & 24 & & 182 & 100 & 106 & 8.0 & 8.0 & 12.5 & 13.5 & 150.0 & 152.5 \\
\hline
\end{tabular}

M: male; F: female; FEV1: forced expiratory volume in one second; FVC: forced vital capacity; BWI: first bronchial wash, recovered volume from a total instillation of $20 \mathrm{~mL}$ phosphate-buffered saline (PBS); BWII: second bronchial wash, recovered volume from a total instillation of $20 \mathrm{~mL}$ PBS; BAL: bronchoalveolar lavage, recovered volume from a total instillation of $180 \mathrm{~mL}(3 \times 60 \mathrm{~mL}$ aliquots) of PBS. 
Exercise was performed using a cycle ergometer situated within the chamber, with a sufficient loading to produce an average minute ventilation of $20 \mathrm{~L} \cdot \mathrm{min}^{-1} \cdot \mathrm{m}^{-2}$ body surface area. Consecutive exposures for each subject were separated by a period of at least 3 weeks to reduce possible carry over effects, arising either from the treatment or the bronchoscopy procedure. Subjects were assigned into groups using a randomization method to equalize between the number of individuals undergoing the air and $\mathrm{O}_{3}$ treatments as their first exposure. The study was conducted in a single-blinded, crossover control fashion with each subject acting as their own control. Lung function tests were carried out before and immediately after each exposure. Fibreoptic bronchoscopy with endobronchial biopsies, bronchial wash (BW) and BAL samples were obtained at $1.5 \mathrm{~h}$ after exposure. Peripheral blood and nasal lavage samples were also obtained from each subject at four time points within the exposure protocol: pre-exposure, $1 \mathrm{~h}$ into the exposure protocol, immediately after exposure, and at $1 \mathrm{~h}$ after exposure. Details of these procedures and results are given in an accompanying article in this issue [12].

\section{Ozone exposure}

Ozone was generated by a Fischer's $\mathrm{O}_{3}$ generator 500 MM (Fischer Labor und Verfahrens-Technik, Bonn, Germany) and the concentration of $\mathrm{O}_{3}$ in the chamber monitored continuously using a photometric $\mathrm{O}_{3}$ analyser (Dasibi model 1108; Dasibi Environmental Corp., Glendale, CA, USA). During $\mathrm{O}_{3}$ exposures ambient air was continuously drawn through the chamber with a ventilation rate of $30 \mathrm{~m}^{3} \cdot \mathrm{h}^{-1}$, conditioned to a temperature of $20^{\circ} \mathrm{C}$ and with a relative humidity of $50 \%$. The mean \pm SD $\mathrm{O}_{3}$ chamber concentration for all exposures was $198.1 \pm 7.7$ parts per billion (ppb).

\section{Lung function assessments}

The lung function tests (performed in triplicate) were carried out before and immediately after each exposure. The dynamic spirometry included measurements of FEV1, FVC, forced mid-expiratory flow (FEF25-75) and flowvolume registrations using conventional spirometry (Vitalograph-COMPACT; Vitalograph Ltd., Buckingham, UK). Since changes in FEF25-75 and flows at different parts of FVC are dependent on changes in FVC the flows were also corrected to predicted total lung capacity (TLC), using the FEF at 50 and $60 \%$ of predicted TLC (FEF50\%TLC and FEF60\%TLC, respectively) [13]. The area under the curve (AUC) was also determined as it has been suggested to be a sensitive indicator of airway bronchoconstriction [14].

\section{Bronchoscopies}

Premedication with atropine $(1 \mathrm{mg})$ was given subcutaneously $30 \mathrm{~min}$ prior to bronchoscopy and lidocaine was used for topical anaesthesia of the airways as in previous studies $[11,15]$. A fibreoptic bronchoscope (Olympus BF type IT200, Tokyo, Japan) was inserted through the mouth via a protective mouthpiece with the subject in the supine position. At each bronchoscopy, at least three endobronchial mucosal biopsy specimens were taken with fenestrated forceps (FB-21C; Olympus). The biopsy samples were taken from either the anterior aspect of the main carina and the subcarinae of the third to fourth generation airways of the right side or from the posterior aspect of the main carina and the corresponding subcarinae on the left side. Different locations were used between the two bronchoscopies in order to avoid biopsy artefacts at former sampling sites. BW was performed by instillation of $2 \times 20 \mathrm{~mL}$, followed by a BAL consisting of $3 \times 60 \mathrm{~mL}$ of sterile phosphate-buffered saline (PBS), $\mathrm{pH} 7.3$, at $37^{\circ} \mathrm{C}$. The lavage fluid was infused with the tip of the bronchoscope carefully wedged in either a lingula lobe bronchus (when biopsies were taken on the right side) or a middle lobe bronchus (when biopsies were taken on the left side) and gently suctioned back. The recovered aspirate from the first and second $20 \mathrm{~mL}$ instillations of the BW and the pooled BAL fluid were collected into separate siliconized containers, and immediately placed on ice. The first BW (BWI) sample was used for the determination of total and differential cell counts and soluble mediators, the second (BWII) for all other determinations.

\section{Processing of lavage fluid and cells}

Post aspiration, lavage fluid was passed through a nylon filter (pore diameter $100 \mu \mathrm{m}$, Syntab Product AB, Malmö, Sweden) and centrifuged at $400 \times g$ for $15 \mathrm{~min}$ to remove mucus and cellular components. Supernatants were separated from cell pellets, and aliquots of the cell free fluid immediately analysed for lactate dehydrogenase (LDH). The remaining material was divided into aliquots and stored at $-80^{\circ} \mathrm{C}$ prior to analysis. Prior to storage, $100 \mu \mathrm{L}$ of a solution containing $2 \mathrm{mmol} \cdot \mathrm{L}^{-1}$ butylated hydroxytoluene (BHT) and deferoxamine mesylate (DM) were added to $10 \mathrm{~mL}$ aliquots of BWII and BAL fluid samples to be assessed for MDA. Cell pellets derived from the BWI and BAL fluid samples were then resuspended in PBS to a final concentration of $10^{6}$ cells $\cdot \mathrm{mL}^{-1}$ and total and differential leukocyte counts were performed. The total number of cells in the lavage fluid were counted in a Bürker chamber. Cytocentrifuged specimens were prepared with $5 \times 10^{4}$ nonepithelial cells per slide using a Cytospin 3 $\mathbb{R}$ (Shandon Southern Instruments Inc., Sewikly, PA, USA) at $96 \times g$ for 5 min. Cell differential counts were conducted on slides stained with May-Grünwald Giemsa with a total of 400 cells counted per slide. Mast cells were counted in at least 10 visual fields at $\times 160$ magnification on slides stained with acid toluidine blue, and counter stained with Mayer's acid haematoxylin. A fluorescence-activated cell sorter (FACS) flow cytometer (Becton-Dickinson, Stockholm, Sweden) was used to determine macrophage activation (human leukocyte antigen (HLA) DR+). FACs was performed only on cells derived from the BAL fluid fraction.

\section{Soluble mediators}

Total protein, albumin, and LDH were measured with assays from Boehringer Mannheim (Mannheim, Germany) in an auto-analyser at the Department of Clinical Chemistry, University Hospital, Umeå, Sweden. IL-6 and IL-8 were determined with commercially available enzyme linked immunosorbent assay (ELISA) kits (R\&D Systems, 
Abingdon, UK) and myeloperoxidase (MPO) was analysed with a radioimmunoassay (RIA) kit (Kabi Pharmacia Diagnostics, Uppsala, Sweden). Fibronectin concentrations were determined with a double-sandwich ELISA technique (Kabi Pharmacia). Briefly, microtitre plates (NUNC, Roskilde, Denmark) were coated with rabbit-antihuman fibronectin antibodies (Dakopatts, Copenhagen, Denmark) diluted 1:2,000 in carbonate buffer, $\mathrm{pH}$ 9.6. After incubation at room temperature for $24 \mathrm{~h}$ the plates were carefully washed with PBS containing $0.005 \%$ albumin. BW and BAL fluid samples were added in diluted series together with horseradish peroxidase-labelled antihuman fibronectin 1:2,000 (Dakopatts) as a secondary antibody and the plates incubated for a further $90 \mathrm{~min}$. The amount of bound peroxidase, which is proportional to the amount of fibronectin in the sample, was determined by analysing the enzymatic activity on $o$-phenylenediamine. Plasma fibronectin of nephelometric quality, obtained from Sigma Chemicals (Poole, UK) was used as a standard.

\section{Determination of antioxidants and markers of damage}

BWII and BAL fluid were assayed for the following parameters: GSH, GSSG, ascorbic acid (AA), uric acid (UA), $\alpha$-tocopherol, and MDA. GSH and GSSG were determined using the method of BAKER et al. [16] as previously described for BAL fluid [17]. AA and UA were measured using reverse phase high-performance liquid chromatography (HPLC) with electrochemical detection, based on the method of IRIYAMa et al. [18]. $\alpha$-Tocopherol was measured using reverse phase chromatography with detection at $\mathrm{A}_{292 \mathrm{~nm}}$, according to the method of BIERI et $a l$. [19] with the following pre-concentration step. Briefly, $3 \mathrm{~mL}$ of lavage fluid, plus $100 \mu \mathrm{l}$ of an $\alpha$-tocopherol acetate internal control $\left(33 \mathrm{mg} \cdot \mathrm{mL}^{-1}\right.$ in ethanol) were placed in a $5 \mathrm{~mL}$ HPLC vial, sealed with a perforated vial cap and freeze dried over a $24-\mathrm{h}$ period. The resultant sample was reconstituted in $400 \mu \mathrm{L}$ of water, to which 2 $\mathrm{mL}$ of hexane was then added, and the sample thoroughly mixed for $5 \mathrm{~min}$. Following centrifugation at 2,000 $\times \mathrm{g}$ $\left(4^{\circ} \mathrm{C}\right)$ for $5 \mathrm{~min}$, the hexane layer was removed and evaporated to dryness under a continuous stream of $\mathrm{N}_{2}$. Immediately prior to analysis, samples were reconstituted in $200 \mu \mathrm{L}$ of methanol by vigorous agitation on a vortex mixer. HPLC determination of MDA was based on the method of CHIRICO et al. [20] and has been described in detail for BAL fluid [11].

\section{Processing and quantification of bronchial mucosal bi- opsies}

The tissue obtained from biopsy was placed in icecooled acetone containing the protease inhibitors phenylmethyl-sulphonyl fluoride $(2 \mathrm{mM})$ and iodoacetamide $(20$ $\mathrm{nM}$ ) prior to processing into glycol methacrylate (GMA) resin as previously described [21]. The blocks were then stored in airtight containers at $-20^{\circ} \mathrm{C}$ until used for immunostaining.

Sections were cut and stained with monoclonal antibodies (mAbs) as previously outlined [15]. In brief, sections cut to a thickness of $2 \mu \mathrm{m}$ were treated to block endogenous peroxide prior to application of mAbs. Non- specific antibody binding was blocked using undiluted culture supernatant. The primary mAbs $(\mathrm{CD} 3+, \mathrm{CD} 4+$, CD8+, AA1 (mast cell tryptase), (neutrophil elastase) (NE), ICAM-1 (CD54), vascular cell adhesion molecule (VCAM)-1 (CD106) and E-selectin (CD62E) (DAKO, Copenhagen, Denmark), P-selectin (CD62P) (Serotec, Oxford, UK), and EN4 (endothelial marker) (Bio-Zac, Stockholm, Sweden)) were added and incubated at room temperature overnight. After rinsing, biotinylated rabbit anti-mouse immunoglobulin (Ig)G F( $\left(\mathrm{ab}^{\prime}\right)_{2}$ (DAKO) was applied, followed by the streptavidin-biotin-horseradish peroxidase complex. Finally, the stained area was developed with aminoethyl carbazole (AEC) in acetate buffer and hydrogen peroxide to yield a red colour. The sections were then counter stained with Mayer's haematoxylin.

Quantification of endothelial adhesion molecules in submucosal blood vessels was performed by expressing the number of vessels staining with specific antiadhesion $\mathrm{mAb}$ as a percentage of the total vessel complement, revealed by staining with the panendothelial $\mathrm{mAb}$ [22]. The number of stained inflammatory cells was counted separately in the epithelium and submucosa and the total number of positive cells expressed as cells $\cdot \mathrm{mm}^{-1}$ of epithelium and cells $\cdot \mathrm{mm}^{-2}$ of submucosa, respectively. Typical staining patterns were seen, cytoplasmic staining for NE and mast cell tryptase, ring staining for $\mathrm{CD} 3+, \mathrm{CD} 4+$, and CD8+ cells. The length of the epithelium and the area of the submucosa where the cell counts were performed were determined using computer-assisted image analysis (Qwin Colour (RG), Leica Q500MC; Leica, Cambridge, UK). Areas including smooth muscle, glands, large blood vessels, torn or folded tissue within the sections were not included.

\section{Data analysis}

Cell data derived from BWI, BAL fluid, and biopsy samples following air and $\mathrm{O}_{3}$ exposures were all nonparametric (Shapiro-Wilks normality test), as were all soluble mediator, antioxidant/oxidative damage marker concentrations determined in BWII and BAL, and lung function measurements. Expressing data as an absolute change (value after $\mathrm{O}_{3}$ - value after air) did not alter this lack of normality. As no simple transformation was available to correct for this underlying lack of normality, all data were analysed using nonparametric methods. Comparisons between groups, post air versus post $\mathrm{O}_{3}$ exposure, were conducted using Wilcoxon's sign rank test. A significant difference was assumed at the 5\% level. Pulmonary function data were expressed differently as there were both preand post-air and $\mathrm{O}_{3}$ values. Here comparisons were performed between the absolute effect due to air (value post-air exposure - value pre-air exposure) and that arising due to $\mathrm{O}_{3}$ exposure (value post- $\mathrm{O}_{3}$ - value pre- $\mathrm{O}_{3}$ ). Effect correlations were based upon the absolute change in parameter (value post- $\mathrm{O}_{3}$ - value post-air) using the Spearman's rank order correlation. A slight modification was required for pulmonary function data with the overall effect used in the correlation analysis being: (value post- $\mathrm{O}_{3}$ - value pre- $\mathrm{O}_{3}$ ) - (value post-air - value pre-air). Again a significant effect was assumed when $\mathrm{p}<0.05$ (two-tailed). Possible ties between detected associations were assessed using partial correlation analysis. In order that the data set 
Table 2. - Immunohistochemistry data on adhesion molecules in the vascular endothelium

\begin{tabular}{lccc}
\hline Adhesion molecule & Air & $\mathrm{O}_{3}$ & p-value \\
\hline ICAM-1 \% & $41(28-48)$ & $74(62-79)$ & $<0.005$ \\
VCAM-1 \% & $0(0-2)$ & $0(0-5)$ & NS \\
E-selectin \% & $2(0-10)$ & $8(2-22)$ & NS \\
P-selectin \% & $44(34-51)$ & $63(56-73)$ & $<0.005$ \\
\hline
\end{tabular}

The vessels expressing adhesion molecules are quantified as a percentage of total EN4 staining vessels. Data given as median values with 25 th and 75 th percentiles in parentheses. ICAM: intercellular adhesion molecule; VCAM: vascular cell adhesion molecule. Comparison of groups performed using Wilcoxon's signed rank test, a significant difference being assumed when $\mathrm{p}<0.05(\mathrm{n}=13)$.

was not oversampled, only variables which had been shown to be significantly perturbed by $\mathrm{O}_{3}$ exposure were considered. All statistical analyses were performed using the Unistat $($ ) (Unistat Ltd., London, UK) and SPSS $\mathbb{R}$ (SPSS Inc., Chicago, IL, USA) statistical packages on a Windows based platform.

\section{Results}

\section{Immunohistochemistry}

Paired biopsy samples (air versus $\mathrm{O}_{3}$ ) from all 13 subjects were available for vascular endothelial adhesion molecule and submucosal inflammatory cell analysis. Of these, eight pairs were also appropriate for epithelial analysis as one or more of the other pairs had damaged epithelium as a consequence of airway sampling and/or sample preparation. Significant increases in the expression of the vascular endothelial adhesion molecules P-selectin $(\mathrm{p}<0.005)$ and ICAM-1 $(\mathrm{p}<0.005)$ were detected after $\mathrm{O}_{3}$ exposure. Conversely, no changes in vascular endothelial E-selectin or VCAM-1 were apparent (table 2). Significant increases in the number of infiltrating mast cells in the submucosa were also observed: air versus $\mathrm{O}_{3}$ exposure (10 (7-14) versus $35(22-48)$ cells $\left.\cdot \mathrm{mm}^{-2}, \mathrm{p}<0.005\right)$. Mast cells were not detected in the epithelium after either exposure. Neutrophil numbers were not affected by exposure to $\mathrm{O}_{3}$ in either the submucosa $(33(18-52)$ versus $58(40-83)$ cells $\left.\cdot \mathrm{mm}^{-2}\right)$ or the epithelium $(0(0-2)$ versus $2(0-5)$ cells $\left.\cdot \mathrm{mm}^{-2}\right)$. Conversely, the numbers of submucosal T-lymphocytes $(\mathrm{CD} 3+)$ were found to be significantly reduced: air versus $\mathrm{O}_{3}$ exposure (53 (17-71) versus $10(1-30)$ cells $\left.\cdot \mathrm{mm}^{-2}, \mathrm{p}<0.05\right)$, as were the T-lymphocyte subsets CD4+ (22 (10-31) versus $0(0-8)$ cells $\cdot \mathrm{mm}^{-2}$, $\mathrm{p}<0.005)$ and CD8+ (27 (22-46) versus $10(0-24)$ cells. $\left.\mathrm{mm}^{-2}, \mathrm{p}<0.05\right)$. All epithelial T-lymphocyte subtypes were unchanged (air versus $\mathrm{O}_{3}$ cells $\left.\cdot \mathrm{mm}^{-1}\right): \mathrm{CD} 3+(2(0-6)$ versus $0(0-4)), \mathrm{CD} 4+(0(0-2)$ versus $0(0-0))$ and $\mathrm{CD} 8+$ (3 (1-8) versus $0(0-2))$.

\section{Cell parameters in $B W$ and $B A L$}

Paired lavage fluid samples were obtained from 12 subjects with recoveries not differing significantly between the $\mathrm{O}_{3}$ and air exposures (table 1). No significant cell changes were observed in BW samples. In BAL fluid, total cell numbers decreased $(\mathrm{p}<0.005)$, due primarily to a fall in airway macrophages $(\mathrm{p}<0.005)$ (table 3 ). Importantly, the macrophage population remaining after $\mathrm{O}_{3}$ was activated, reflected as an increase in percentage HLA-DR+ macrophages 6 (3-9) (air) versus $14(8-18)\left(\mathrm{O}_{3}\right), \mathrm{p}<0.005$.

\section{Soluble mediators and cytokines}

Total protein, albumin and LDH concentrations in BW and BAL fluid were unchanged following $\mathrm{O}_{3}$ challenge (table 4). However, a trend $(\mathrm{p}<0.06)$ suggestive of a decrease in LDH activity in BW was evident, possibly indicative of oxidative inactivation. BW and BAL fluid IL-6, IL-8, and MPO concentrations were also unaffected by $\mathrm{O}_{3}$ (table 4). Further, no effect of $\mathrm{O}_{3}$ on the concentration of fibronectin was observed: $920(410-1,750)$ (air) versus $480(305-1,410)\left(\mathrm{O}_{3}\right) \mu \mathrm{g} \cdot \mathrm{L}^{-1}$, in BW; and $640(570-720)$ (air) versus $480(380-925)\left(\mathrm{O}_{3}\right) \mu \mathrm{g} \cdot \mathrm{L}^{-1}$, in $\mathrm{BAL}$.

\section{Antioxidants and oxidative damage markers}

Antioxidant and oxidative damage marker concentrations in BW/BAL fluid are summarized in table 5. No evidence of perturbations in AA, UA, or $\alpha$-tocopherol concentrations $\left(\mathrm{O}_{3}\right.$ versus air exposure $)$ were observed. In contrast, GSH concentrations were significantly increased $(p<0.05)$ in both the BW $(4.5$-fold $)$ and BAL fluid (3.1-fold) following $\mathrm{O}_{3}$ exposure. This effect was maintained irrespective of whether concentrations were expressed per unit volume of lavage fluid, corrected for recovery or using lavage fluid total protein as a dilution correction factor (fig. 1). No evidence of an $\mathrm{O}_{3}$-induced effect on GSSG or MDA (BW or BAL fluid) was observed. Plasma antioxidant concentrations were also determined at intervals during the exposure protocol. These data are considered in greater detail in the accompanying article in this issue [12]. However, as it was desirable to address whether $\mathrm{O}_{3}$ exposure induced changes in the airway partitioning ratio ((plasma) $1 \mathrm{~h}$ post-exposure/(BW

Table 3. - Details of first bronchial wash (BWI) and bronchoalveolar lavage (BAL) total and differential cell counts observed $1.5 \mathrm{~h}$ after air and 0.2 parts per million (ppm) $\mathrm{O}_{3}$ exposure

\begin{tabular}{|c|c|c|c|c|c|c|}
\hline \multirow[b]{2}{*}{ Parameter } & \multicolumn{3}{|c|}{ BWI fluid } & \multicolumn{3}{|c|}{ BAL fluid } \\
\hline & Air & $\mathrm{O}_{3}$ & $\mathrm{p}$-value & Air & $\mathrm{O}_{3}$ & $\mathrm{p}$-value \\
\hline All cells $\times 10^{4} \cdot \mathrm{mL}^{-1}$ & $16.0(8.3-24.8)$ & $9.0(5.8-15.6)$ & NS $(p=0.06)$ & $16.2(13.1-19.6)$ & $10.0(6.6-12.5)$ & $<0.005$ \\
\hline Neutrophils $\times 10^{4} \cdot \mathrm{mL}^{-1}$ & $0.5(0.3-1.2)$ & $0.7(0.6-1.7)$ & NS & $0.2(0.1-0.2)$ & $0.1(0.1-0.2)$ & NS \\
\hline Macrophages $\times 10^{4} \cdot \mathrm{mL}^{-1}$ & $14.8(6.7-23.8)$ & $7.1(4.0-12.0)$ & NS & $14.9(11.2-17.8)$ & $9.1(5.5-11.3)$ & $<0.005$ \\
\hline Lymphocytes $\times 10^{4} \cdot \mathrm{mL}^{-1}$ & $0.6(0.4-1.0)$ & $0.3(0.1-0.5)$ & NS & $0.8(0.5-1.6)$ & $0.8(0.6-1.2)$ & NS \\
\hline Mast cells $\times 10^{4} \cdot \mathrm{mL}^{-1}$ & $0.6(0.3-1.0)$ & $0.3(0.1-0.4)$ & NS $(p=0.07)$ & $0.4(0.3-0.8)$ & $0.3(0.2-0.5)$ & NS \\
\hline
\end{tabular}

Comparisons between post-air and $\mathrm{O}_{3}$ concentration performed using the Wilcoxon signed rank test ( $\mathrm{n}=12$ in all cases). 
Table 4. - First bronchial wash (BWI) and bronchoalveolar lavage (BAL) fluid soluble component concentrations $1.5 \mathrm{~h}$ after air and 0.2 parts per million (ppm) $\mathrm{O}_{3}$ exposure

\begin{tabular}{|c|c|c|c|c|c|c|}
\hline \multirow[b]{2}{*}{ Parameter } & \multicolumn{2}{|c|}{ BWI fluid } & \multicolumn{3}{|c|}{ BAL fluid } & \multirow[b]{2}{*}{ p-value } \\
\hline & Air & $\mathrm{O}_{3}$ & p-value & Air & $\mathrm{O}_{3}$ & \\
\hline Protein $\mu \mathrm{g} \cdot \mathrm{mL}^{-1}$ & $140(80-230)$ & $130(60-160)$ & NS & $120(50-180)$ & $70(70-120)$ & NS \\
\hline Albumin $\mu \mathrm{g} \cdot \mathrm{mL}^{-1}$ & $32.5(15.5-60.0)$ & $29.0(10.0-29.0)$ & NS & $36.5(26.3-48.8)$ & $39.0(31.0-45.0)$ & NS \\
\hline $\mathrm{LDH} \mu \mathrm{kat} \cdot \mathrm{L}^{-1}$ & $1.0(0.5-1.6)$ & $0.6(0.4-0.8)$ & NS $(p=0.06)$ & $0.4(0.2-0.8)$ & $0.3(0.2-0.4)$ & NS \\
\hline MPO $\mu \mathrm{g} \cdot \mathrm{L}^{-1}$ & $5.0(3.3-13.2)$ & $9.3(4.4-11.6)$ & NS & $2.8(2.0-3.2)$ & $2.6(2.4-2.8)$ & NS \\
\hline IL-6 $\mathrm{pg} \cdot \mathrm{mL}^{-1}$ & $7.0(4.1-10.8)$ & $6.0(4.8-10.8)$ & NS & $7.0(3.5-41.3)$ & $8.5(4.6-26.0)$ & NS \\
\hline IL-8 $\mathrm{pg} \cdot \mathrm{mL}^{-1}$ & $91.0(47.8-161)$ & $94.0(64.5-129)$ & NS & $23.5(19.3-36.3)$ & $24.0(18.3-28.8)$ & NS \\
\hline
\end{tabular}

Data illustrated as median values with 25 th and 75 th percentiles in parentheses. LDH: lactate dehydrogenase; MPO: myeloperoxidase; IL: interleukin. Comparisons between post-air and $\mathrm{O}_{3}$ concentration performed using the Wilcoxon signed rank test $(\mathrm{n}=12)$. $(1 \mathrm{~kat}=1$ $\mathrm{mol} \cdot \mathrm{s}^{-1}$.)

or BAL) $1.5 \mathrm{~h}$ post-exposure) of the antioxidants in the distal lung, plasma concentrations obtained at $1 \mathrm{~h}$ post exposure were used here. The mean concentrations of plasma antioxidants at this time point following both air and $\mathrm{O}_{3}$ exposures were as follows: AA 24.6 (14.6-29.7) (air) versus $32.3(29.2-36.7)\left(\mathrm{O}_{3}\right) \mu \mathrm{mol} \cdot \mathrm{L}^{-1}$; UA 275 (151-326) (air) versus $301(231-388)\left(\mathrm{O}_{3}\right) \mu \mathrm{mol} \cdot \mathrm{L}^{-1}$; and $\alpha$-tocopherol 12.9 (11.1-15.4) (air) versus 13.7 (11.515.6) $\left(\mathrm{O}_{3}\right) \mu \mathrm{mol} \cdot \mathrm{L}^{-1}$. The GSH partitioning ratio was not calculated, as plasma levels of this moiety were not determined in the present study. A significant decrease in the UA $(p=0.01)$, and increase in the $\alpha$-tocopherol $(p<0.05)$ partitioning ratios between the plasma and BAL fluid (distal RTLF) compartments was observed (table 6).

\section{Lung function}

Primary spirometric measurements, FVC, FEV1, and FEF25-75, were all found to be depressed following $\mathrm{O}_{3}$ exposure compared with control air responses $(p<0.05$, $\mathrm{p}<0.01$ and $\mathrm{p}<0.005$, respectively) (fig. 2). Data were modified for the confounding effects of changes in FVC on FEF25-75 and the flows at different parts of FVC, and the adjusted values FEF50\%TLC, FEF60\%TLC and AUC were calculated. In all these variables, significant changes were detected in the difference across the $\mathrm{O}_{3}$ exposure compared to across the air exposure $(\mathrm{p}<0.005, \mathrm{p}<0.005$ and $\mathrm{p}<0.005$, respectively) (fig. 3 ).

\section{Correlation analysis}

No evidence was found that alterations in primary or modified spirometric measurements were related to the changes observed in early inflammatory or RTLF redox status following $\mathrm{O}_{3}$ exposure. However, a significant positive correlation was found between the change $(\Delta) \mathrm{HLA}-$ $\mathrm{DR}+$ macrophages and $\triangle \mathrm{ICAM}-1(\mathrm{r}=0.78, \mathrm{p}<0.005)$.

\section{Discussion}

In this study, bronchial mucosal biopsies and antioxidant measurements were examined to study the early events occurring after $\mathrm{O}_{3}$ exposure, and hence provide near-contemporaneous correlates to $\mathrm{O}_{3}$-induced pulmonary function decrements. The major findings were as follows: 1) upregulation of P-selectin and ICAM-1 in the vascular endothelium concurrent with increased submucosal mast cell numbers; 2) decreased macrophage numbers in the airways, with enhanced activation of the remaining subset; 3) increased levels of GSH in the RTLF, with altered partition ratios between the plasma and RTLF pools for UA and $\alpha$-tocopherol; 4) significant lung function responses indicative of small airway narrowing; and 5) no evidence of a simplistic association between inflammatory and RTLF redox responses with the functional decrements observed.

Both mucosal and airway neutrophilia were absent $1.5 \mathrm{~h}$ after a 2-h exposure to $0.2 \mathrm{ppm}_{3}$ in subjects performing moderate exercise $\left(20 \mathrm{~L} \cdot \mathrm{min}^{-1} \cdot \mathrm{m}^{-2}\right)$. Previously, increases in neutrophil numbers have been reported in BAL as early as $1 \mathrm{~h}$ post-exposure following a 2-h exposure to $0.4 \mathrm{ppm}$ $\mathrm{O}_{3}$, [5] as well as in a proximal airway sample following exposure to $0.3 \mathrm{ppm} \mathrm{O}_{3}$ for $1 \mathrm{~h} \mathrm{[10]}$. These studies utilized high exercise levels $\left(60 \mathrm{~L} \cdot \mathrm{min}^{-1}\right)$ and consequently much higher $\mathrm{O}_{3}$ doses than used in the present study, which may explain this discrepancy.

Table 5. - Second bronchial wash (BWII) and bronchoalveolar lavage (BAL) fluid antioxidant/oxidant damage marker concentrations $1.5 \mathrm{~h}$ after air and 0.2 parts per million $(\mathrm{ppm}) \mathrm{O}_{3}$ exposure

\begin{tabular}{|c|c|c|c|c|c|c|}
\hline \multirow[b]{2}{*}{ Parameter } & \multicolumn{3}{|c|}{ BWII fluid } & \multicolumn{3}{|c|}{ BAL fluid } \\
\hline & Air & $\mathrm{O}_{3}$ & p-value & Air & $\mathrm{O}_{3}$ & $\mathrm{p}$-value \\
\hline Ascorbate $\mu \mathrm{mol} \cdot \mathrm{L}^{-1}$ & $0.45(0.31-1.38)$ & $0.93(0.68-1.77)$ & NS & $0.57(0.33-0.84)$ & $0.97(0.55-1.42)$ & NS \\
\hline Urate $\mu \mathrm{mol} \cdot \mathrm{L}^{-1}$ & $0.75(0.54-1.19)$ & $0.88(0.71-1.35)$ & NS & $1.50(0.94-1.78)$ & $0.95(0.59-1.94)$ & NS \\
\hline $\mathrm{GSH} \mu \mathrm{mol} \cdot \mathrm{L}^{-1}$ & $0.39(0.22-1.01)$ & $1.77(0.52-2.51)$ & $<0.05$ & $0.50(0.35-0.71)$ & $1.55(0.94-2.14)$ & $<0.05$ \\
\hline$\alpha$-Tocopherol $\mu \mathrm{mol} \cdot \mathrm{L}^{-1}$ & $0.17(0.15-0.22)$ & $0.15(0.13-0.17)$ & NS & $0.13(0.10-0.16)$ & $0.12(0.11-0.14)$ & NS \\
\hline GSSG $\mu \mathrm{mol} \cdot \mathrm{L}^{-1}$ & $0.19(0.08-0.33)$ & $0.32(0.12-0.48)$ & NS & $0.30(0.01-0.15)$ & $0.00(0.00-0.14)$ & NS \\
\hline MDA $\mu \mathrm{mol} \cdot \mathrm{L}^{-1}$ & $1.96(0.75-2.30)$ & $2.51(1.34-4.23)$ & NS & $2.90(2.52-3.55)$ & $3.12(1.82-3.98)$ & NS \\
\hline
\end{tabular}

Data illustrated as median values with 25 th and 75th percentiles in parentheses. GSH: reduced glutathione; GSSG: glutathione disulphide; MDA: malondialdehyde. Comparisons between post-air and $\mathrm{O}_{3}$ concentration performed using the Wilcoxon signed rank test $(\mathrm{n}=12)$. 

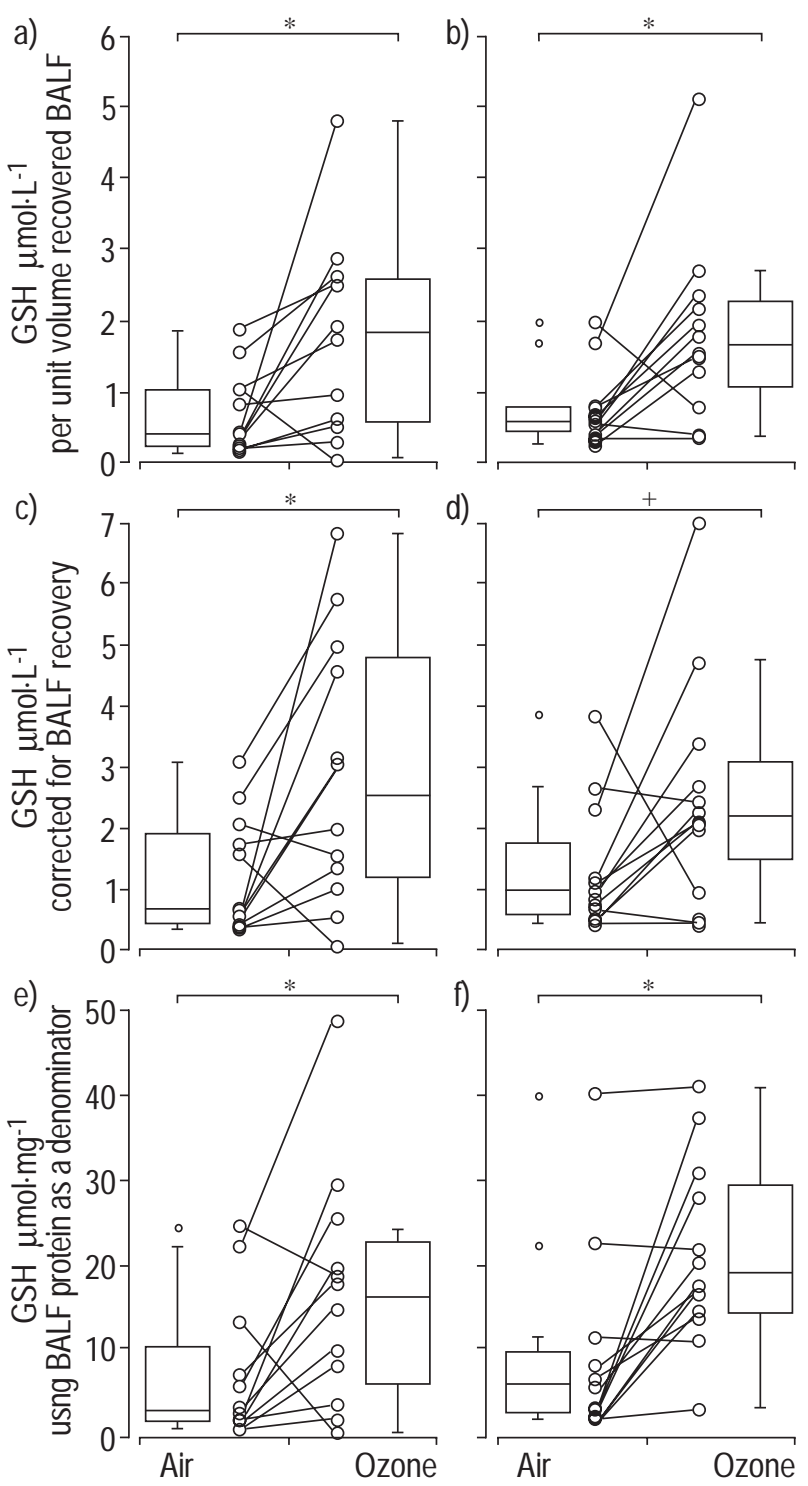

Fig. 1. - Reduced glutathione (GSH) concentrations in second bronchial wash $(\mathrm{a}, \mathrm{c}, \mathrm{e})$ and bronchoalveolar lavage fluid (BALF; b, d, f) obtained from subjects $(n=12) 1.5 \mathrm{~h}$ post-air and 0.2 parts per million (ppm) $\mathrm{O}_{3}$ exposure. Results are expressed as box plots (median, 25th and 75 th percentiles and $\pm 1.5 \times$ interquartile range with individual outliers shown) using three commonly employed conventions for expressing lavage fluid data: 1) per unit volume of recovered lavage fluid $(\mathrm{a}, \mathrm{b})$; 2) concentrations corrected to assume a $100 \%$ lavage fluid recovery (c, d); and 3) using lavage fluid protein as a denominator to correct for variations in dilution $(\mathrm{e}, \mathrm{f})$. Significant differences between concentrations post-air and $\mathrm{O}_{3}$ exposure were detected using Wilcoxon's sign rank test. $*$ : $\mathrm{p}<0.05 ;^{+}: \mathrm{p}=0.07$.
The increased P-selectin expression found in this study confirms previous observations at $0.12 \mathrm{ppm} \mathrm{O}_{3}$ using the same sampling point [8]. While the selectins are involved in the early phase of leukocyte-endothelial adhesion, ICAM-1 is considered important during stronger leukocyte adhesion to the endothelial surface and subsequent migration from the vasculature [23]. Here ICAM-1 expression was also elevated. A significant negative correlation between the two markers $\left(r_{s}=-0.51 ; p<0.05\right)$ was observed, suggesting that ICAM-1 upregulation followed the P-selectin increase. Recently, BALMES et al. [6] reported increased expression of ICAM-1 in endobronchial biopsies $18 \mathrm{~h}$ following a 4-h exposure to $0.2 \mathrm{ppm} \mathrm{O}_{3}$ suggesting that the increase in ICAM-1 was persistent over this time frame. In the present study, no evidence was seen of neutrophil migration into the bronchial mucosa. This suggested that although the expression of vascular adhesion molecules had increased by $1.5 \mathrm{~h}$ after exposure, this had not yet resulted in a movement of neutrophils from the circulating pool. Significant increases in mucosal neutrophils have been previously reported in human subjects $18 \mathrm{~h}$ after a 4 -h challenge to $0.2 \mathrm{ppm} \mathrm{O}_{3}$ [4] suggesting that $1.5 \mathrm{~h}$ is too early to see this developing tissue inflammation.

To the best of the authors' knowledge, no previous human data are available on mast cell responses in bronchial biopsies following $\mathrm{O}_{3}$ exposure and the increase in submucosal mast cells seen here is therefore a novel finding. No effects on mast cells were found at the lower $\mathrm{O}_{3}$ concentration $(0.12 \mathrm{ppm})$ [8], indicating a dose threshold. A similar increase in submucosal mast cell numbers has recently been reported after exposure to diesel exhaust fumes [24] suggesting some commonality in the airway response to these challenges. Furthermore, in a guinea-pig model, an early increase in mast cell numbers has been observed in biopsies following exposure to a high $\mathrm{O}_{3}$ concentration [25]. In this model, the increase in mast cells was associated with increased bronchial hyperreactivity, suggesting an association between the two responses [25]. Increased airway responsiveness after $\mathrm{O}_{3}$ exposure has also been shown in humans [26], but no previous studies have addressed the association between airway hyperreactivity and mast cells numbers (activity) following exposure to $\mathrm{O}_{3}$. Studies in mice suggest that mast cells may modulate the influx of neutrophils and alter lung permeability induced by $\mathrm{O}_{3}$ exposure [27]. Whether mast cells play a similar modulating role in the response of human airways to $\mathrm{O}_{3}$ is still unclear and requires further investigation, but the current observations would support their involvement in the early $\mathrm{O}_{3}$-induced response. Mast cells are an important source of several

Table 6. - Antioxidant partitioning ratios $1.5 \mathrm{~h}$ post-air and 0.2 parts per million (ppm) $\mathrm{O}_{3}$ exposures in second bronchial wash (BWII) and bronchoalveolar lavage (BAL) fluid

\begin{tabular}{|c|c|c|c|c|c|c|}
\hline \multirow[b]{2}{*}{ Parameter } & \multicolumn{3}{|c|}{ BWII fluid } & \multicolumn{3}{|c|}{ BAL fluid } \\
\hline & Air & $\mathrm{O}_{3}$ & $\mathrm{p}$-value & Air & $\mathrm{O}_{3}$ & $\mathrm{p}$-value \\
\hline Ascorbate & $40.9(12.2-101)$ & $34.5(12.6-98.1)$ & NS & $46.6(12.6-50.0)$ & $50.2(17.2-55.4)$ & NS \\
\hline Urate & $334(177-492)$ & $210(112-394)$ & NS & $292(220-362)$ & $231(147-279)$ & $=0.01$ \\
\hline$\alpha$-Tocopherol & $74.0(53.4-99.7)$ & $94.9(77.1-117)$ & NS & $87.2(69.4-104)$ & $107(88.9-122)$ & $<0.05$ \\
\hline
\end{tabular}

Partition ratio $=(($ plasma $) 1 \mathrm{~h}$ post exposure $) /((\mathrm{BW}$ or BAL $) 1.5 \mathrm{~h}$ post exposure $)$. Values expressed as medians with 25 th and 75 th percentiles in parentheses. Comparison between post-air and $\mathrm{O}_{3}$ values using Wilcoxon's signed rank test $(n=12)$ 

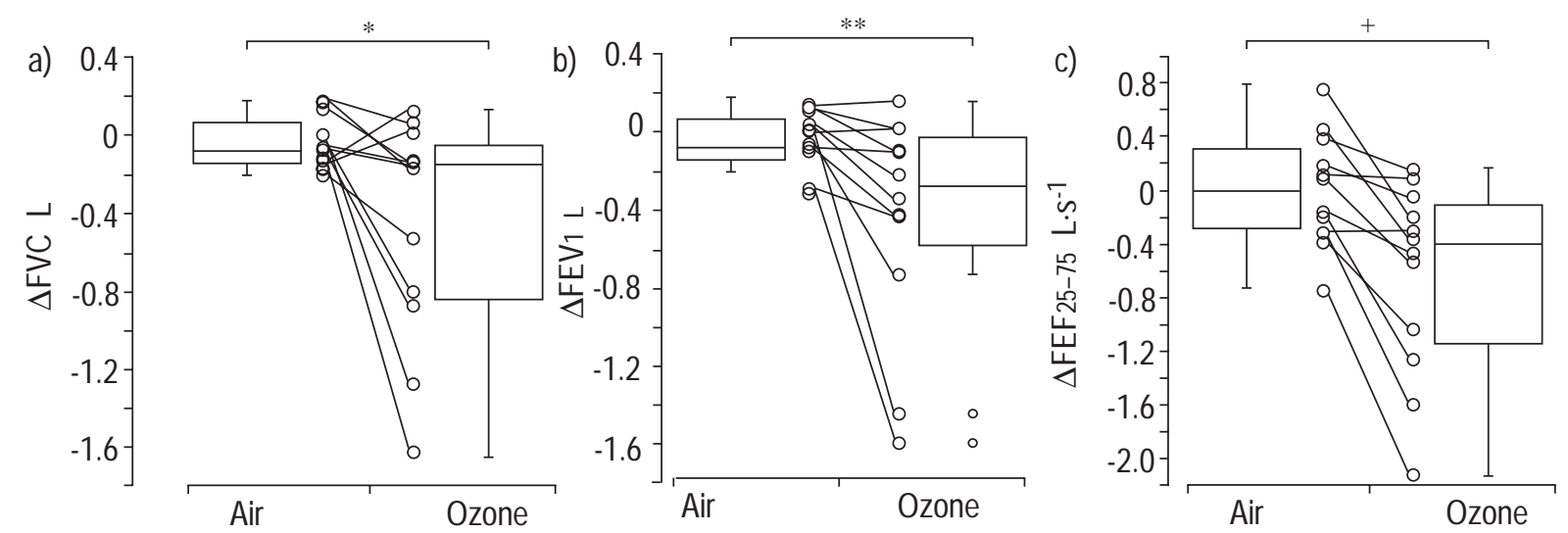

Fig. 2. - Change $(\Delta)$ in forced vital capacity (FVC; a), forced expiratory volume in one second (FEV1; b) and forced mid-expiratory flow (FEF25-75; c) pulmonary function parameters immediately post-air and $\mathrm{O}_{3}$ exposure. Box plots represent median, 25 th and 75 th percentiles and $\pm 1.5 \times$ interquartile range with individual outliers shown. Significant differences between the magnitude of response post-air and $\mathrm{O}_{3}$ exposure were detected using Wilcoxon's sign rank test. *: $\mathrm{p}<0.05 ;{ }^{* *}: \mathrm{p}<0.01 ;^{+}: \mathrm{p}<0.005(\mathrm{n}=13)$.

pro-inflammatory cytokines such as tumour necrosis factor (TNF)- $\alpha$, GM-CSF, transforming growth factor (TGF)$\beta$, IL-1, IL-3 and IL-6 and may therefore play a role in modulating the recruitment of polymorphonuclear cells to the interstitium. Whilst no evidence was found that the increase in mucosal mast cells was translated to the airway lumen at $1.5 \mathrm{~h}$ post-exposure, FRAMPTON et al. [28] recently reported increased mast cell numbers in BAL 18 $\mathrm{h}$ after exposure to $0.2 \mathrm{ppm} \mathrm{O}_{3}$ suggesting that such a movement may indeed occur.

In the present study, a highly significant decrease in submucosal T-lymphocytes (CD3+) and in the CD4+ and $\mathrm{CD} 8+$ lymphocyte subsets following $\mathrm{O}_{3}$ exposure was observed. This novel and unexpected finding may reflect the internalization of (or damage to) T-cell surface markers, but may also be evidence of oxidative stress-initiated apoptosis of the lymphocyte population or migration to the airway lumen, lymphatic ducts or blood vessels. If migration of lymphocytes into the airway lumen had occurred, an increased number would have been expected in the lavage samples. No such change was observed. Currently, no additional data are available on lymphocyte responses in bronchial biopsies following $\mathrm{O}_{3}$. In BAL, however, FRAMPTON et al. [28] reported an increase in lymphocyte numbers late $(18 \mathrm{~h})$, but not immediately, after exposure to $0.22 \mathrm{ppm} \mathrm{O}_{3}$ for $4 \mathrm{~h}$.

In agreement with the findings of FRAMPTON et al. [28], a significant decrease in macrophage numbers was found in the present study in BAL fluid after $\mathrm{O}_{3}$ exposure. This may reflect direct $\mathrm{O}_{3}$ toxicity, inducing cell death, or altered membrane adhesive properties making the cells more difficult to wash from the airways. Flow cytometry was performed on the remaining cells and demonstrated an increased percentage of HLA-DR+ macrophages, a marker indicative of cell activation. Potential consequences of this early macrophage activation are difficult to delineate, but export of GSH and elaboration of early pro-inflammatory cytokines may represent two potentially important mechanisms.

RTLF represents the first physical interface encountered by inspired agents [29]. As a consequence of this barrier function, and its possession of a range of antioxidants (UA, AA, GSH, and $\alpha$-tocopherol) which are highly reactive towards $\mathrm{O}_{3}[29]$, it was hypothesized that effects on these moieties were likely to reflect some of the earliest effects of $\mathrm{O}_{3}$ on the airways. Of the antioxidants examined, only GSH was significantly affected by $\mathrm{O}_{3}$, increasing in both BW and BAL fluid $1.5 \mathrm{~h}$ post-exposure.
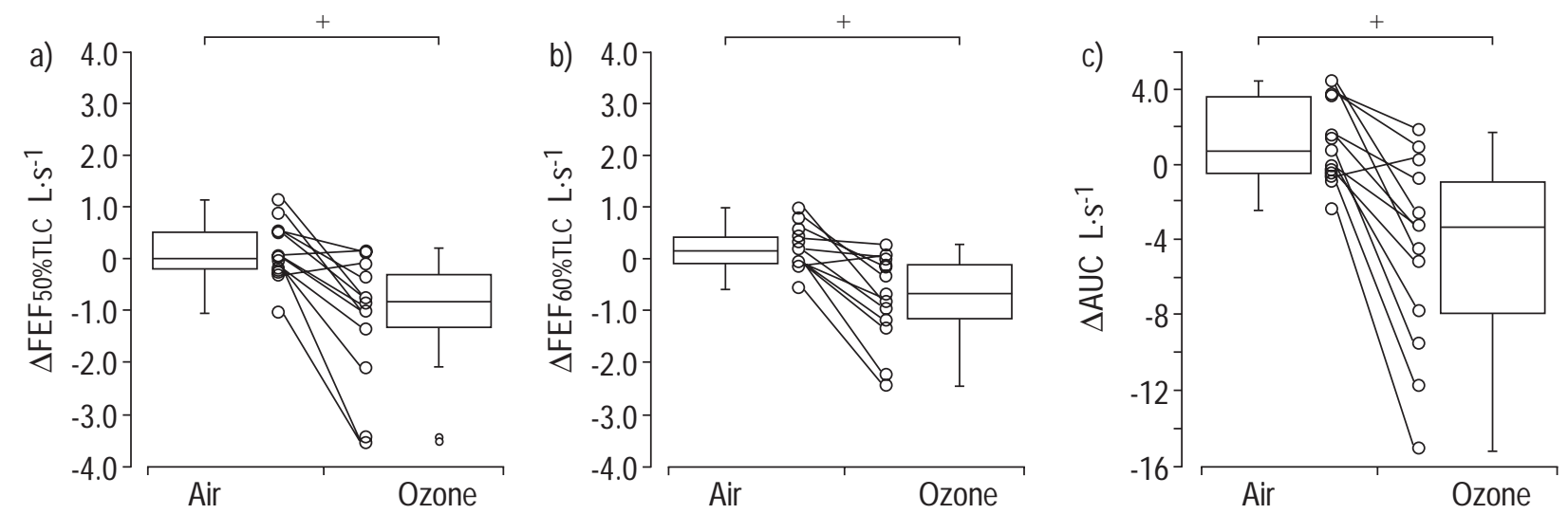

Fig. 3. - Change $(\Delta)$ in forced expiratory flow at $50 \%$ of predicted total lung capacity (FEF50\%TLC; a), forced expiratory flow at $60 \%$ of predicted total lung capacity (FEF60\%TLC; b), and total area under curve (AUC; c) immediately post-air and $\mathrm{O}_{3}$ exposure. Box plots represent median, 25 th and 75 th percentiles and $\pm 1.5 \times$ interquartile range with individual outliers shown. Significant differences between the magnitude of response post-air and $\mathrm{O}_{3}$ exposure were detected using Wilcoxon's sign rank test. ${ }^{+}: \mathrm{p}<0.005(\mathrm{n}=13)$. 
This increase in RTLF GSH concentrations is similar to that reported previously following $\mathrm{NO}_{2}$ challenge [11], and observed in the airways of chronic cigarette smokers [30], a group known to be under considerable oxidative stress [31]. The increase in GSH may be interpreted as either 1) reflective of cellular lysis with passive release of GSH into the RTLF, or 2) export with or without increased synthesis from cellular (type II pneumocytes, macrophages or Clara cells) stores. Of note, is that the increase in RTLF GSH was associated with the temporal decrease in BAL fluid macrophage numbers, although no quantitative relationship between the two processes could be detected. Whilst synthesis of GSH is well-characterized [32], little is presently understood about the export of this moiety into RTLF. The action of $\mathrm{O}_{3}$ on resident airway macrophages in rabbits has been shown to result in increased intracellular GSH concentrations; an increase subsequently transferred to the extracellular compartment [33]. However, whilst this mechanism is consistent with the observed results, the time course occurs over days, and not hours as observed in this study, suggesting that the increase in BW/BAL fluid GSH was more likely to be a function of macrophage death than a regulated adaptive response.

RTLF AA and UA concentrations were unchanged $1.5 \mathrm{~h}$ post- $\mathrm{O}_{3}$ exposure. It has previously been demonstrated ex vivo that these moieties are rapidly consumed by $\mathrm{O}_{3}$ [17] and therefore this finding was unexpected. Furthermore, $\mathrm{NO}_{2}$ exposure had previously been shown to result in significant decreases in the RTLF concentrations of both these moieties in human subjects [11]. It is possible that RTLF AA and UA concentrations did fall during the actual $\mathrm{O}_{3}$ exposure period, but that these losses rapidly resolved through repletion by the $1.5 \mathrm{~h}$ post-exposure sampling time. If this was the case, one might expect the ratio of the concentration of these moieties across the plasma/RTLF pools to have altered, reflecting movement from one pool, to offset loss in the other. In order to determine whether this was the case, partition ratios (postair and $-\mathrm{O}_{3}$ exposure) were determined. This approach revealed a decreased ratio for UA following $\mathrm{O}_{3}$, suggesting increased RTLF concentrations relative to plasma, and an increased ratio for $\alpha$-tocopherol, suggesting increased plasma concentrations relative to RTLF levels. Movement of UA from the plasma pool to RTLF to offset oxidative loss has previously been proposed [34]. Indeed, several groups $[11,35]$ have reported increased concentrations of UA following oxidant gas challenge consistent with movement from plasma to RTLF. Similarly, mobilization of $\alpha$-tocopherol to the lung has been reported in a range of animal models exposed to $\mathrm{O}_{3}$ [36]. It therefore appears that as early as $1.5 \mathrm{~h}$ post- $\mathrm{O}_{3}$ exposure an adaptation of the RTLF antioxidant screen (increased GSH, movement of UA from plasma to RTLF pools and mobilization of nonlung tissue $\alpha$-tocopherol into plasma) to offset earlier changes in this compartment, is occurring.

Significant decreases in FVC and FEV1 after $\mathrm{O}_{3}$ exposure were observed, consistent with previous studies [37, $38]$ but in contrast to a previous study using $0.12 \mathrm{ppm} \mathrm{O}_{3}$ [8]. Effects on FEV1 are believed to occur as a consequence of decreased FVC mediated through involuntary inhibition of inspiration [37, 39]. In this study, FEV1 decrements paralleled those for FVC $(r=0.8, p<0.005)$ consistent with this view. FEF25-75 was also significantly reduced after $\mathrm{O}_{3}$ exposure as previously reported [28]. As FEF25-75 is a volume dependent measurement, decreases in FVC following $\mathrm{O}_{3}$ would effect this parameter. WEINMANN et al. [40] concluded that this effect could be accounted for if isovolume adjustments were made, and that FEF25-75 then represented a useful means of assessing intrinsic airway narrowing. Therefore forced expiratory flow values were expressed at the same fraction, 50 and $60 \%$ of TLC (FEF50\%TLC and FEF60\%TLC, respectively) in this study according to a model of HEDENSTRÖM and MALMBERG [13]. A significant reduction in both FEF50\%TLC and FEF60\%TLC following $\mathrm{O}_{3}$ exposure was observed indicating that the change in forced expiratory flow could not be explained solely as a function of reduced $\mathrm{FVC}$, but that small airway narrowing was occurring, consistent with previous reports [40]. Further support for this contention was observed as AUC also fell post- $\mathrm{O}_{3}$ challenge. This index is thought to reflect functional changes of whole expiration and to be a sensitive indicator of bronchoconstriction [13, 41]. It has been shown that reductions in FEF25-75 follow a different time course to $\mathrm{O}_{3}$-induced changes in FVC [40] and consequently it has been argued that pulmonary dysfunction after $\mathrm{O}_{3}$ exposure may consist of two (or more) separate components, including limited inspiratory capacity and airway narrowing. In order to examine the possibility that small airway narrowing had occurred in the authors' previous study at $0.12 \mathrm{ppm}$ [8], retrospective analysis of the forced expiratory flows was performed as outlined above. No significant changes in FEF50\%TLC, FEF $60 \%$ TLC or AUC were detected at this $\mathrm{O}_{3}$ concentration, indicating that the pulmonary decrements observed at $0.2 \mathrm{ppm} \mathrm{O}_{3}$ represented a dose-dependent effect.

Detailed literature exists describing both the immediate pulmonary responses of humans exposed to $\mathrm{O}_{3}$ and the subsequent development (6-18 h) of airway inflammation [1]. A number of studies have related immediate lung function responses to indices of airway inflammation determined $1-18 \mathrm{~h}$ after exposure, using higher $\mathrm{O}_{3}$ burdens than employed in the present study $[2,10,42]$. SCHELEGLE et al. [10] found no significant correlations between the immediate $\mathrm{O}_{3}$-induced FEV1 and the neutrophil responses at 1,6 and $24 \mathrm{~h}$ post-exposure. However, a trend towards an inverse relationship was found at the $6 \mathrm{~h}$ timepoint. A similar inverse correlation between the immediate FEV1 decrement and BAL fluid neutrophil percentage at $18 \mathrm{~h}$ was reported by ARIS et al. [4]. A recent study with a similar design failed to detect any relationship between FEV1 decrements and indices of airway inflammation. However, a significant association was found between the increase in airway resistance and the percentage neutrophils and total protein concentration in BAL fluid following $\mathrm{O}_{3}$ challenge [6]. In the present study, immediate lung function changes were related to the bronchoscopy findings $1.5 \mathrm{~h}$ post-exposure. Since bronchoscopy needs certain pretreatment it is not easy to reduce the temporal interval between the bronchoscopy and lung function measurement further. No significant correlations were detected between any of the lung function parameters and early inflammatory responses, antioxidant levels or neutrophil counts.

Based on the present and previous data, it seems unlikely that there is any simplistic relationship between $\mathrm{O}_{3}$-induced lung function decrements and airway inflammation. 
The lack of a relationship between early indices of airway inflammation and pulmonary effects suggests that lung function measurements are not a good indicator of subsequent $\mathrm{O}_{3}$-induced lung injury. Failure to detect any associations between respiratory tract lining fluid redox changes and the pulmonary and inflammatory responses observed $1.5 \mathrm{~h}$ after exposure may be indicative of a temporal disassociation between an adapting response and a developing airway inflammation. Clearly therefore, the events which are likely to be most pertinent are the immediate redox changes occurring within this compartment during the challenge period. Serial bronchoscopy is obviously impractical and other less invasive ways of monitoring the respiratory tract lining fluid are therefore required to resolve this issue.

Acknowledgements. The authors acknowledge the valuable technical assistance of $\mathrm{H}$. Bertilsson, L. Skedebrant, M-C. Ledin, U. Hammarström, A. Hagenbjörk-Gustafsson, J. Pourazar and A-B. Lundström

\section{References}

1. Bascom R, Bromberg PA, Costa DA, et al. Health effects of outdoor air pollution. Am J Respir Crit Care Med 1996; 153: 3-50

2. Devlin RB, McDonnell WF, Mann R, et al. Exposure of humans to ambient levels of ozone for 6.6 hours causes cellular and biochemical changes in the lung. Am J Respir Cell Mol Biol 1991; 4: 72-81.

3. Koren HS, Devlin RB, Graham DE, et al. Ozone-induced inflammation in the lower airways of human subjects. $\mathrm{Am}$ Rev Respir Dis 1989; 139: 407-415.

4. Aris RM, Christian D, Hearne PQ, Finkbeiner WE, Balmes JR. Ozone-induced airway inflammation in human subjects as determined by airway lavage and biopsy. Am Rev Respir Dis 1993; 148: 1363-1372.

5. Koren HS, Devlin RB, Becker S, Perez R, McDonnell WF. Time dependent changes of markers associated with inflammation in the lungs of humans exposed to ambient levels of ozone. Toxicol Path 1991; 19: 406-411.

6. Balmes JR, Aris R, Chen LL, et al. Airway inflammation and responsiveness to ozone in normal and asthmatic subjects (Part 1). Health Effects Institute Research Report 1997; 78: 1-37.

7. Seltzer J, Bigby BG, Stulborg M, Hottzman MJ, Nadel JA. Ozone induced change in bronchial reactivity in metacholine and airway inflammation in humans. J Appl Physiol 1986; 60: 1321-1326.

8. Krishna MT, Blomberg A, Biscione GL, et al. Short-term ozone exposure upregulates P-selectin in normal human airways. Am J Respir Crit Care Med 1997; 155: 17981803.

9. Weinmann GG, Liu MC, Proud D, Weidenbach-Gerbase M, Hubbard W, Frank R. Ozone exposure in humans: inflammatory, small and peripheral airway responses. $\mathrm{Am}$ $J$ Respir Crit Care Med 1995; 152: 1175-1182.

10. Schelegle ES, Siefkin AD, McDonald RJ. Time course of ozone-induced neutrophilia in normal humans. Am Rev Respir Dis 1991; 143: 1353-1358.

11. Kelly FJ, Blomberg A, Frew AJ, Holgate ST, Sandström T. Antioxidant kinetics in lung lining fluid following exposure of human to nitrogen dioxide. Am J Respir Crit Care Med 1996; 154: 1700-1705.
12. Mudway IS, Blomberg A, Frew AJ, Holgate ST, Sandström T, Kelly FJ. Antioxidant consumption and repletion kinetics in nasal lavage fluid following exposure of healthy human volunteers to ozone. Eur Respir J 1999; 13: 1429-1438.

13. Hedenström H, Malmberg P. Utility of relating pulmonary airflow measures to total lung capacity. Bull Eur Physiopathol Respir 1986; 22: 559-564.

14. Sovijarvi ARA. Flow-volume response to inhaled methacholine in asthmatics; comparison of area under the curve (AFV) with conventional parameters. Eur J Respir Dis 1986; 68: 18-21.

15. Blomberg A, Krishna MT, Bocchino V, et al. The inflammatory effects of 2 ppm $\mathrm{NO}_{2}$ on the airways of healthy subjects. Am J Respir Crit Care Med 1997; 156: 418-424.

16. Baker MA, Cerniglia GJ, Zaman A. Microtiter plate assay for the measurement of glutathione and glutathione disulfide in large numbers of biological samples. Anal Biochem 1990; 190: 360-365.

17. Mudway IS, Housley D, Eccles R, et al. Differential depletion of human respiratory tract antioxidants in response to ozone challenge. Free Rad Res 1996; 25: 499-513.

18. Iriyama K, Yoshiura M, Iwamoto T, Ozaki Y. Simultaneous determination of uric and ascorbic acids in human serum by reversed-phase high-performance liquid chromatography with electrochemical detection. Anal Biochem 1984; 141: 238-243.

19. Bieri JG, Poukka RKH, Prival EL. Determination of alpha-tocopherol in erythrocytes by gas-liquid chromatography. J Lipid Res 1970; II: 118-123.

20. Chirico S, Smith C, Marchant C, Mitchinson MJ, Halliwell B. Lipid peroxidation in hyperlipidaemic patients, a study of plasma using an HPLC based thiobarbituric acid test. Free Rad Res Comms 1993; 19: 51-57.

21. Britten KM, Howarth PH, Roche WR. Immunohistochemistry on resin sections: a comparison of resin embedding techniques on small mucosal biopsies. Biotech Histochem 1993; 68: 271-280.

22. Montefort S, Gratziou C, Goulding D, et al. Bronchial biopsy evidence for leucocyte infiltration and upregulation of leucocyte-endothelial adhesion molecules 6 hours after local allergen challenge of sensitised asthmatic airways. J Clin Invest 1994; 93: 1411-1421.

23. Hamacher J, Schaberg T. Adhesion molecules in lung diseases. Lung 1994; 172: 189-213.

24. Salvi SS, Blomberg A, Rudell B, et al. Acute inflammatory responses in the airways and peripheral blood following short term exposure to diesel exhaust in healthy human volunteers. Am J Respir Crit Care Med 1999; 159: 702-709.

25. Murlas C, Roum JH. Bronchial hyper-reactivity occurs in steroid treated guinea-pigs depleted of leukocytes by cyclophosphamide. J Appl Physiol 1985; 58: 16301637.

26. Folinsbee LJ, Horstman DH, Kehrl HR, Harder S, AbdulSalaam S, Ives PJ. Respiratory responses to repeated prolonged exposure to $0.12 \mathrm{ppm}$ ozone. Am J Respir Crit Care Med 1994; 149: 98-105.

27. Kleeberger SR, Seiden JE, Levitt RC, Zhang L-Y. Mast cells modulate acute ozone-induced inflammation of the murine lung. Am Rev Respir Dis 1993; 148: 1284-1291.

28. Frampton MW, Morrow PE, Torres A, et al. Effects of ozone on normal and potentially sensitive human subjects. Part II: Airway inflammation and responsiveness to ozone in nonsmokers and smokers. Health Effects Institute Research Report 1997; 78: 39-72. 
29. Pryor WA. Mechanisms of radical formation from reactions of ozone with target molecules in the lung. Free Rad Biol Med 1994; 17: 451-465.

30. Cantin AM, North SL, Hubbard RC, Crystal RG. Normal alveolar epithelial lining fluid contains high levels of glutathione. J Appl Physiol 1987; 63: 152-157.

31. Rahman I, MacNee W. Role of oxidants/antioxidants in smoking-induced lung diseases. Free Rad Biol Med 1996; 21: 669-681.

32. Meister A. New aspects of glutathione biochemistry and transport-selective alteration of glutathione metabolism. Nutr Rev 1984; 42: 397-410.

33. Boehme DS, Maples KR, Henderson RF. Glutathione release by pulmonary alveolar macrophages in response to particles in vitro. Toxicol Lett 1992; 60: 53-60.

34. Eccles R. A role for the nasal cycle in respiratory defence. Eur Respir J 1996; 9: 371-376.

35. Koren HS, Hatch GE, Graham DE. Nasal lavage as a tool in assessing acute inflammation in response to inhaled pollutants. Toxicology 1990; 60: 15-25.

36. Elasyed NM. Vitamin E: Mobilization of vitamin E to the lung under oxidative stress. In: Diplock AT, Machlin LJ, Packer L, Pryor WA, eds. Biochemistry and Health Impli- cations. New York, New York Academy of Sciences, 1989; pp. 439-440.

37. Hazucha MJ. Relationship between ozone exposure and pulmonary function changes. J Appl Physiol 1987; 62: 1671-1680.

38. McDonnell WF, Horstman DH, Hazucha MJ, et al. Pulmonary effects of ozone exposure during exercise: dose response characteristics. J Appl Physiol 1983; 54: 13451352.

39. Coleridge JCG, Coleridge HM, Schelegle ES, Green JF. Acute inhalation of ozone stimulates bronchial C-fibers and rapidly adapting receptors in dogs. J Appl Physiol 1993; 74: 2345-2352.

40. Weinmann GG, Bowes SM, Gerbase MW, Kimball AW, Frank R. Response to acute ozone exposure in healthy men. Am J Respir Crit Care Med 1995; 151: 33-40.

41. Vermaak JC, Bunn AE, de Kock MA. A new lung function index. The area under the maximum expiratory flow-volume curve. Respiration 1979; 37: 61-65.

42. Balmes JR, Chen LL, Scannell S, et al. Ozone-induced decrements in FEV1 and FVC do not correlate with measures of inflammation. Am J Respir Crit Care Med 1996; 153: 904-909. 